\title{
Information Mining Capabilities in Malaysian SMEs: Specific Use of Enterprise Resource Planning System
}

\author{
N. Zulkifli, R.G. Hashim, J. Ahmad \\ Faculty of Administrative Science \& Policy Studies \\ Universiti Teknologi MARA (UiTM) \\ Shah Alam, Malaysia \\ syahidazulkifli@gmail.com,guy73106@yahoo.com,jasmine_ahmad@hotmail.com
}

\begin{abstract}
Information mining has never been more crucial in organizational decision making than now. Without information and communication technologies (ICTs), most companies, particularly the small and medium enterprises (SMEs) would not be able to survive the demands of the current volatile economic conditions. Hence, this paper reports the findings from the assessment of ICT usage by 110 SMEs in the Klang Valley, Malaysia. Specifically, the usage of enterprise resource planning system (ERP) was assessed and the outcome showed that SMEs in Malaysia are still lagging in computer usage for improved organizational decision. The implications for non-usage bode negatively for SME's sustained survival although the government continued to offer assistance through the annual budget allocation. The findings of this study showed that the perceived ease of use and perceived usefulness had significant relationship with the ERP system usage. A strong and visionary leader would provide the basis to push the SMEs to achieve better returns of investment.
\end{abstract}

Keywords-Small Medium Enterprises; Information and Communication Technology; Enterprise Information System; Enterprise Resource Planning; Socio Psychological Factors; Malaysia

\section{INTRODUCTION}

Information mining is a process and methodology to extract numerous of data into meaningful information [1] in order to support the decision making and strategic planning for the organization [2]. The information mining is the sub-discipline of information system (IS) to provide the analysis and synthesis tools to extract the available data from different information sources [1]. The unpredictable development of information and communication (ICT) in industries affect the organizational functions. The ICT usage is important for competitive advantage in challenging business environment [3]. One of the ICT tools for small and medium enterprises (SMEs) to increase their effectiveness and competitiveness in global market is the enterprise resource planning (ERP) system [4]. Specifically, ERP is a sub-system of enterprise information system (EIS), a customized application which ensures an efficient and effective information flow for any organization. To be exact, EIS is defined as "business model in the organization consists of various types of businesses, business processes, organization, information systems and information mining, which circulate across the enterprise" [5]. Some of the common examples of EIS applications are ERP, Supply Chain Management (SCM), Customer Relation Management (CRM),
Knowledge Management System (KMS) and Product Life Cycle Management [5].

SMEs play a significant role in the economic development of the country and are considered the backbone of industrial development in Malaysia [6][7][8]. Besides, Malaysian SMEs also contributed 37 percent to gross domestic product (GDP) [9]. Similarly, the economic sustenance of other developed countries like Japan, Korea, German, China, Taiwan and others are dependent of SME actitivies [8]. Nonetheless, the role of SMEs in the economic growth of Malaysia can be determined by looking at their contribution in the three main sectors which are manufacturing, services and agriculture [7]. Furthermore, the SMEs accounted for a significant percentage in the total amount of businesses in Malaysia's economic sectors [4]. 99.2 percent of the companies that operated in Malaysia are defined as SMEs. Most of the manufacturing enterprises in Malaysia concentrated in the central region like Wilayah Persekutuan and Selangor [6].

ERP system usage is common among SMEs in the developed countries and realized that this system adoption has proven to add value to their business [10]. Most of the Malaysian SMEs have not fully embraced technology as the enabler for the organizational success [11] although the government has allocated huge budgets for the SMEs to do so. A percentage of Malaysia's annual budget has consistently been allocated for SMEs. This included the recent 2012 Budget where the Prime Minister reiterated the important role of SMEs to the nation's economy. Also, the 2012 Budget RM100 million has been allocated for SMEs to revitalize their business through the use of ICT [12].

According to Tan and Eze [13], the ICT implementation among Malaysian SMEs like e-commerce and e-business are still in infancy stage with most relying on computer for simple accounting and word processing. In fact, the usage of advanced technologies such as ERP, CRM and SCM systems are unfamiliar because their usefulness and benefits have not fully recognized by SMEs [14]. The emergence of ERP system in the past decade in Malaysia has still not been widely adopted by SMEs because of high cost and complex system implementation [15]. Moreover, Malaysian government has recognized and acknowledged the importance of the ERP system to the success of SMEs as stated in Small Medium 
Industries Development Plan (SMIDP 2001-2005) [16]. With that, the aim of this paper is to explore the profile of SMEs in Selangor and also investigate the relationship and influence of socio psychological factors towards ERP system usage among SMEs in Selangor.

\section{LITERATURE REVIEW}

\section{A. Concept of ERP system}

Within the ICT context, the ERP system is defined as a computer program that integrates the important functions within the company into a single system to fulfill the needs of the different departments [17]. It means that every department can share the information and communicate with each other easily because the ERP integrates them into a single computer system. Hence, this is an opportunity for the SMEs to improve their businesses as many large companies have invested in the ERP implementation in order to remain competitive and relevant in the face of globalization [4]. Generally, the ERP system is perceived as a complex project management process because it involves resources like money, time and employees. However, several studies demonstrated positive effects of socio psychological factors on the technology adoption success [18][19][20] and ERP implementation such as top management support, and involvement and effective project management [21][22][23][24][25]. Leaning on these evidences, the socio psychological factors are operationalized in this study because they involve the employees' perceptions, attitude and belief on system usage [21]. This means that the employees are directly involved with the technological changes.

With the growth of technology usage in the organization, the employee acceptance towards the changes has become the important issue for the management of the resources especially in term of financial and time. In some cases, the organizations fail to gain benefits from the ERP system implementation. The common reason for the failure is resistance to change of employees to accept the ERP system. Therefore, the management should understand the employees' acceptance and usage of ERP system to ensure the successful of ERP system. The ERP system also known as an enterprise system is software system consisting modules for supporting functional areas. The design of the ERP system facilitates the integration of modules and provides flow of information between all functions within the organizations transparently. ERP system allows the organizations to implement one integrated system by replacing their incompatible legacy information systems [27]. ERP system integrates all the resource planning for the organizations to cover functional areas like engineering, finance, human resources and project management. ERP is a computerised system that integrates a number of areas and activities into one accounting information system. Therefore, ERP integrates all the units and functions throughout the organization into a single system so that the employees can make decision by refering to all the business operation [28].
The definitions of ERP system are discussed differently from technical view to holistic business perspective, however the definitions do not contain major differences. Therefore, the authors define the ERP system as a software package that integrates all the information and of all the departments in the organization into one system so that the information can be shared and used by the other departments. The functional areas consist of functions manufacturing, sales, marketing, engineering logistic and distribution, accounting, financial, human resource management, services and maintenance, project management, and inventory management. Information system usage has been studied by numerous scholars eg. Chang et al.[26]. Chang et al. [26] studied the key factors that determine the ERP system usage by using Triandis model. There are three main factors which are organizational, individual and technological which affected the ERP system usage. The authors proposed that the ERP system usage was measured by using intensify and frequency of ERP use

The research theory on socio-psychological factors is basically based on Triandis's (1980) socio-psychological framework [26]. This theory suggests that there are six factors that influence the individual to perform the intention and behavior towards the tasks [29] such as the effects of performing that behavior, social factors, perceived consequences, habit of performing similar tasks, facilitating conditions and intention [19]. Originally, this model was only used for sociology research, but eventually, it has been used in other disciplines including information system research. Furthermore, there are a number of potential factors that could influence the usage of ERP system. The researchers and scholars are exploring the user acceptance towards the system implementation have developed many theories and models (eg. Davis et al., 1989). Many literatures discussed the direct and indirect effect of perceived usefulness (PU) and ERP system usage. In the TAM model, there are two shared beliefs (PU and ease of use) that influence the intention the users to use the systems as well as affect the systems usage. The original TAM model indicated that these shared beliefs significantly influence system usage either directly or indirectly [30][31][32][33]. In addition, the PU had significant effect on the ERP system usage. The finding showed that the employees used the ERP system because they believed the system was useful for them especially in improving their job performance, thus led to the ERP system usage among the employees [34]. Nonetheless, the PU was not supported having direct effect on actual usage [30].

Besides, PEOU was positively and significantly benefited the ERP system usage. It showed that PEOU influenced the ERP system usage because when the users believed that the system is easy to use then leads to the positive attitude towards ERP usage. The finding clearly explained that the perception that ERP system is easy to use, thus led to the positive attitude towards using it [11]. In contrast, the PEOU had no significant effect with the actual usage [36][30] but the PEOU had significant and positive effect on the ERP system usage [30]. 
Zhang et al. [24] studied on the factors that affect the users' intention to use the ERP systems. The finding indicated that the social influence is the stronger predictor to the individual's intention to use that system where $\beta=0.508$ with the $p=0.000$. The social influence is defined as the individual's acceptance and usage of the ERP systems may be influenced by the opinion of the important person in that organization. Thus, the social influence might affect the other's peception such as colleagues, towards the ERP systems usage. The reward is also important factors that can encourage the employees to use the ERP system countinously. The reward can be intrinsic or extrinsic which is considered as a compensation for their effort for using ERP system. The reward should be considered as a success factor of ERP system usage in order to face the user resistance [37]. According to Kamhawi [38], the ERP sytems usage can improve productivity, reduce inventory, new improvement processes and customer responsiveness. Genoulaz and Millet [39] emphasized that the company may perceive the benefits in term of costs, operational and relationship with external customers, for instance suppliers. Besides, the ERP usage also reduces the information redundancy, work in real-time and all the data from the departments in the organization are combined in one system. Therefore, the reduction of direct cost like IT cost which is one of the main objectives of the ERP system implementation and usage in the organization. It shows that the effect of the ERP system usage in the organizations can benefit them in various ways. The organizations may experience a lot of benefits from the successful ERP systems implementation.

ERP system implemenation rate in developing countries of Asia is very low [40]. As well as in Malaysia, the system implemention is also low. It shows that there is lack of empirical evidence about the social psychological factors that encourage to the ERP system usage especially in Malaysian SMEs. This study explores the profile of SMEs in Klang Valley, Selangor and also investigates the influence of socio psychological factors and ERP system usage among SMEs in Klang Valley, Selangor. This study contributes to the understanding of the management to know factors responsible for an employee's behavior towards the ERP system usage. Based on the factors explored from the literature, a conceptual framework is proposed as shown in Figure 1. In this framework, the socio-psychological factors which are perceived usefulness, perceived ease of use, rewards, social influence and perceived benefits are the independent factors which have effect on the ERP system usage.

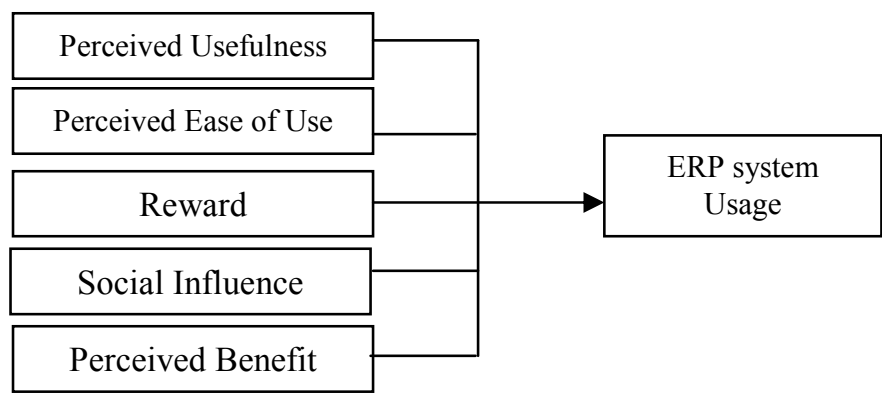

\section{Figure 1: Conceptual Framework}

\section{RESEARCH HYPHOTHESES}

In order to achieve this research objective, following research hypotheses are formulated.

H1 - All the socio psychological factors have significant relationship with ERP system usage

H2 - All the socio psychological factors influence the relationship with ERP system usage

\section{RESEARCH Methodology}

\section{A. Respondents}

Questionnaires were mailed to SMEs in the manufacturing including agro-based and manufacturing related services sector in Klang Valley, Selangor through electronic mail (email). The 300 questionnaires were emailed and only 250 were returned. Thus, the response rate was 66.7 percent. However, only 110 questionnaires were completely answered and used for data analyses by using Statistical Software Package for Social Sciences (SPSS). Otherwise, 140 questionnaires were excluded from data analysis because they are not complete and non user of ERP system. A pre testing of fifty questionnaires were conducted in order to verify the various measurements of questions such as language, ease of completing the questionnaire and appropriate questions related to the ERP system usage behavior [41]. The result of pre test of this study shows that the Cronbach's alpha value is .7 which is the construct variables are reliable and understand by the respondents.

\section{B. Measurement}

The questions were adapted from the previous literature related to the factors examined in this study. A five-point Likert scale questions was used based on the items adapted from Chang et al. [26], Suppramaniam and Kuppusamy [35] and Davis [40]. The scale ranges from 1 to 5 which strongly disagree (1), disagree (2), neutral (3), agree (4) and strongly agree (5). Table 1 illustrates the measurements and constructs items used for each variables of this study.

Table 1: Measurement of Construct Variables

\begin{tabular}{|l|l|l|}
\hline Variables & Measurement & Items \\
\hline $\begin{array}{l}\text { Perceived } \\
\text { usefulness }\end{array}$ & $\begin{array}{l}\text { Employees encouraged using } \\
\text { the ERP system when they } \\
\text { perceived that the ERP system } \\
\text { is very useful in completing } \\
\text { their daily tasks [40] }\end{array}$ & $\begin{array}{l}\text { ERP system is useful if } \\
\text { their tasks can be } \\
\text { completed quickly, } \\
\text { improve job } \\
\text { performance and } \\
\text { increase productivity }\end{array}$ \\
\hline $\begin{array}{l}\text { Perceived } \\
\text { ease of use }\end{array}$ & $\begin{array}{l}\text { "Less effort" to use the ERP } \\
\text { system [40] }\end{array}$ & $\begin{array}{l}\text { Easy to learn the ERP } \\
\text { system, easy to operate, } \\
\text { flexible to interact, and } \\
\text { clear and easy to } \\
\text { understand. }\end{array}$ \\
\hline Rewards & $\begin{array}{l}\text { Recognition from the top } \\
\text { management either in the form } \\
\text { of financial and non financial } \\
\text { rewards [29] }\end{array}$ & $\begin{array}{l}\text { Recognition of the top } \\
\text { management to the } \\
\text { employees that using } \\
\text { the ERP system in }\end{array}$ \\
\hline
\end{tabular}




\begin{tabular}{|l|l|l|}
\hline & & $\begin{array}{l}\text { completing their tasks } \\
\text { such as congratulates, } \\
\text { praises, compensates } \\
\text { and bonuses }\end{array}$ \\
\hline $\begin{array}{l}\text { Perceived } \\
\text { benefits }\end{array}$ & $\begin{array}{l}\text { Performance outcome of the } \\
\text { organizations after using the } \\
\text { ERP system [39] }\end{array}$ & $\begin{array}{l}\text { Lowering cost of } \\
\text { operation, reduce } \\
\text { information } \\
\text { redundancy, improve } \\
\text { quality of business and } \\
\text { adapt with the business } \\
\text { changes }\end{array}$ \\
\hline $\begin{array}{l}\text { Social } \\
\text { influence }\end{array}$ & $\begin{array}{l}\text { Acceptance and usage of the } \\
\text { ERP system influenced by the } \\
\text { support and opinion from the } \\
\text { important person in the } \\
\text { organization [41] }\end{array}$ & $\begin{array}{l}\text { Support from the top } \\
\text { management, superior } \\
\text { and colleagues to } \\
\text { influence the ERP } \\
\text { system usage. }\end{array}$ \\
\hline
\end{tabular}

\section{RESULT}

\section{A. Reliability Analysis}

The reliability of the questionnaire can be analyzed by using the Cronbach's alpha. The Cronbach's alpha is needed to determine the reliability of the measure for the study variable. The acceptable Cronbach's Alpha reliability coefficient is 0.6 and reliability over 0.8 is considered good [42][43][44]. It is important to ensure that the questions asked in the questionnaire are reliable and easy to understand by the respondents. The $\alpha$ values for all the variables are above 6 which is acceptable and the measurements used are reliable and understand by the respondents. The $\alpha$ values for ERP system usage (dependent variable) is .73; and the $\alpha$ values for independent variables are perceived usefulness is .87; perceived ease of use is .77; reward is .62; perceived benefit is .76 ; and social influence is .95 .

\section{B. Demographic Profile}

In order to explore the profile of ERP system user among SMEs in Klang Valley, Selangor, descriptive statistics were done.

Table 2: Profile of Respondents

\begin{tabular}{|c|c|c|}
\hline \multirow[t]{2}{*}{ Items } & \multicolumn{2}{|c|}{$\mathrm{N}=\mathbf{2 5 1}$} \\
\hline & Frequency & Percentage (\%) \\
\hline \multicolumn{3}{|l|}{ Gender } \\
\hline Male & 152 & 60.6 \\
\hline Female & 99 & 39.4 \\
\hline Average Total Employees & \multicolumn{2}{|c|}{115} \\
\hline Average Age of Business & \multicolumn{2}{|c|}{ 10years } \\
\hline Average of ERP Usage & \multirow{2}{*}{\multicolumn{2}{|c|}{2 years }} \\
\hline Experience & & \\
\hline Annual Sales Turnover & \multicolumn{2}{|c|}{ Between RM10m and RM25m } \\
\hline
\end{tabular}

Table 2 above shows the distribution of the respondents. Mostly of the respondents are male $(60.6 \%)$ and the rest is female $(39.4 \%)$. The average number of employees and age of business are 115 and 10 years respectively. Moreover, the average of the experience in using ERP system among the respondents is 2 years and the annual sales turnover of the companies are between RM10m and RM25m.

\section{Hypotheses Testing}

I. Relationship between socio psychological factors with ERP system usage

Table 3: Pearson Correlation Analysis of Socio Psychological Factors toward ERP system Usage

\begin{tabular}{|c|c|c|c|c|c|c|c|}
\hline No & Construct Variables & 1 & 2 & 3 & 4 & 5 & 6 \\
\hline 1 & ERP system Usage & 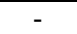 & & & & & \\
\hline 2 & Perceived Usefulness & $.69 * *$ & - & & & & \\
\hline 3 & $\begin{array}{l}\text { Perceived Ease of } \\
\text { Use }\end{array}$ & $.60 * *$ & $.76^{* *}$ & - & & & \\
\hline 4 & Rewards & -.15 & -.03 & -.66 & - & & \\
\hline 5 & Perceived Benefits & -.02 & -.11 & -.17 & $-.38 * *$ & - & \\
\hline 6 & Social Influence & .03 & .10 & .12 & $-.33 * *$ & -.18 & - \\
\hline
\end{tabular}

Table 3 illustrates that only two socio-psychological factors were significantly correlated with the ERP system usage where perceived usefulness $(\mathrm{r}=.69, \mathrm{p}<.01)$ and perceived ease of use $(\mathrm{r}=.60, \mathrm{p}<0.01)$. On the other hand, the rewards $(\mathrm{r}=-.15, \mathrm{p}=0.32)$, the perceived benefits $(\mathrm{r}=-.12$, $\mathrm{p}=.88)$ and social influence $(\mathrm{r}=.03, \mathrm{p}=.75)$ were not significantly correlated with the ERP system usage because the significant values, $\mathrm{p}$, are greater than 0.05 .

\section{Table 4: Regression Analysis of Socio Psychological Factors toward ERP system Usage}

\begin{tabular}{lc}
\hline \multirow{1}{*}{ Construct Variables } & ERP System Usage \\
\cline { 2 - 2 } & Standardize $\boldsymbol{\beta}$ \\
\hline Perceived Usefulness & .53 \\
Perceived Ease of Use & .26 \\
Rewards & -.19 \\
Perceived Benefits & -.01 \\
Social Influence & -.11 \\
\hline R $^{2}$ & .52 \\
Adjusted R & \\
F & .50 \\
Sig F change & 22.78 \\
Durbin-Watson & .00 \\
\hline
\end{tabular}

Table 4 explains the regression analysis of the socio psychological factors toward ERP system usage. The ERP system usage is the dependent variable and socio psychological factors (perceived usefulness, ease of use, rewards, perceived benefits and social influence) are predictors in this study. The $\mathrm{R}^{2}$ value shows that the independent variables explain 52\% variation in the ERP system usage. Thus, the model best fits and explains significant variation in the usage behavior. The standardize $\beta$ values which give a measure of the contribution of each independent variables to the model. The large $\beta$ value indicates that a unit change in these independent variables has 
large effect on the dependent variable. From the regression analysis, the perceived usefulness $(\beta=0.53, p<0.05)$ is the most influential factors in determining the ERP system usage. It means that the perceived usefulness is the most important factor for the ERP system usage. Then, followed by the perceived ease of use $(\beta=0.23, p<0.05)$ and the rewards $(\beta=-$ $.17, \mathrm{p}=.05)$ were factors to influence the ERP system usage. So, the perceived ease of use, rewards and perceived usefulness are the significant factors to influence ERP system usage in this model while, perceived benefits $(\beta=-.01, p=.91)$, and social influence $(\beta=-.08, p=.116)$ were not significantly influenced the ERP system usage.

\section{DISCUSSION AND CONCLUSION}

The findings showed that most of the respondents are the medium-sized of SMEs with the annual sales turnover between RM10 million and RM25 million; and the average number of employees are 115. This study confirmed that the small-sized SMEs in Selangor area could also afford to purchase and use the ERP system besides the medium-sized SMEs. The average age of business among the SMEs in Selangor is 10 years. It shows that majority of the users of ERP system are the medium sized of SMEs in Selangor. Besides, the mean value for the ERP system usage experience among SMEs in Selangor is two (2) years which is considered as low. The mean value which is less than 3 is considered as low level of ERP system usage while the mean value greater than 3 indicated high level of ERP system usage [39]. However, this finding cannot generalize the level of the ERP system usage among SMEs in Selangor as a whole because this study not focused to the SMEs in all the Selangor's area.

This findings proved that the little usage of the ERP system and still not popular among SMEs in Selangor, Malaysia, while, in contrast with the national programmes developed by Malaysia Government namely economic transformation plan (ETP), government transformation programme (GTP), national key result area (NKRA) and RMK 10. The Budget 2012 announced by the Prime Minister (PM) of Malaysia has been allocated sufficiently to the SMEs in order to revitalize their business through ICT usage. The allocation of budget for the SMEs is important to make sure the objectives of these programmes can be realized especially for the technology usage. Therefore, this is contrary to the Malaysian government initiatives to encourage more ICT usage in the businesses such as internet, business to business (B2B), business to customers (B2C) and advanced technology [13].

The findings showed that the perceived ease of use and perceived usefulness are significantly correlated with the ERP system usage. The ERP system usage enabled the employees to complete their task quickly and improved the job performance and productivity. Besides, the employers need to perceive the usefulness of using the ERP system to the employees rather than using the traditional methods.
Therefore, the employees were more confident to use the ERP system to replace the former system in their daily tasks [40; 45]. Besides, the management should ensure the employees perceived the ERP system is easy to use and not complicated in order to increase the ERP system among the employees in SMEs $[40 ; 45]$. The rewards are not significantly related with ERP system usage and this finding contrast with the study done by Ramjattan (2008) because the SMEs, especially small and medium-sized, lack financial resources in order to provide the financial rewards to the employees in learning to use the ERP system and having insufficient knowledge about what the ERP system can provide and not sure about the benefits that can be derived from the ERP system implementation and usage. So, it can cause the SMEs lack of confident to use the ERP system in their organizations.

The perceived usefulness and perceived ease of use of the ERP system significantly influenced the ERP system usage, which is similar to the study done by Garaca [46] on the variables affecting the used of ERP system among the students. Therefore, the second hypothesis, all the socio psychological factors influence the relationship with ERP system usage, is rejected because only perceived usefulness, ease of use and rewards have significantly influence the ERP system usage in SMEs in Selangor. This present study explains only $50 \%$ variation in the ERP system usage behavior of employees. Another $50 \%$ of usage behavior is still unmeasured. Therefore, future research is needed to explore further variables to measure the ERP system usage behavior which was not measured in this present study.

\section{ACKNOWLEDGMENT}

Special thanks to Research Management Institute (RMI) Universiti Teknologi MARA (UiTM) for the grants provided in order to complete this paper.

\section{REFERENCES}

[1] G-M. Ramon, B. Poala, P. Patricia, B. Rodolfo, P-C. Florencia, R. Dario, P. Pablo, and V. Juan, "Towards an Information Mining Engineering," Sello Editorial Universidad de Medellín, pp. 83-99, 2011.

[2] J. Schiefer, J-J. Jeng, S. Kapoor, and P. Chowdhary, "Process Information Factory: A Data Management Approach for Enhancing Business Process Intelligence," IBM Watson Research Center, 2010.

[3] A. Noudoostbeni, N. Mohd Yasin, and H. Jenatabadi, "To Investigate The Success and Failure Factors of ERP implementation within Malaysian Small and Medium Enterprises," IEEE Computer Society, pp. 157-160, 2009.

[4] S. Shahawai, and I. Idrus, "Research methodology for assesing Malaysian SMEs perspective on ERP," IEEE Computer Security, pp. 407-412, 2009.

[5] K. Hendricks, V. Singhal, and J. Stratman, "The impact of enterprise systems on corporate performance: A study of ERP, SCM, and CRM system implemetation," Journal of Operations Management, vol. 25, pp. $65-82,2007$.

[6] A. Saleh, and N. Ndubisi, "An Evaluation of SME Development in Malaysia," International Review of Business Research Papers, vol. 2 (1), pp. 1-14, 2006 
[7] N. Mohd Asri, "SMEs: Buiding Blocks for Economic Growth," Natonal Statistics Conference Department of Statistics, Malaysia, Malaysia: Department of Statistics, Malaysia, pp. 1-13, 2006.

[8] A. Radam, M. Abu, and A. Abdullah, "Technical Efficiency of Small and Medium Enterprise in Malaysia: A Stochastic Frontier Production Model," International Journal of Economics and Management, vol. 2 (2), pp. 395-408, 2008.

[9] P. Wong, "RM500mil for innovative", The Sun, pp.2, (2012, May 11).

[10] Benroider, E., \& Koch, S., "ERP selection process in midsize and large organizations", Business Process Management Journal , 7 (3), 251-257, 2005.

[11] A. Yusuf, A. Gunasekaran, and M. Abthorpe, "Enterprise information systems project implementation: A case study of ERP in Rolls-Royce," International Journal Production Economics, vol. 87, pp. 251-266, 2000

[12] J. Timbuong \& G. Goh Budget 2012 offering SME a boost, The Star TechCentral, Oct. 10, 2011.

[13] K. Tan, and U. Eze, "An Empirical Study of Internet-Based ICT Adoption Among Malaysian SMEs", Communication of the IBIMA , 1, 1-10. 2008

[14] UNDP, "Chapter 2: Challenge of globalization for SMEs" In UNDP, Malaysian Small and Medium Enterprises Building: An Enabling Environment. Malaysia, 2007

[15] F. Goni, A. Chofreh, and S. Sahran, "Critical Success Factors for Enterprise Resource Planning System Implementation: A Case Study in Malaysian SME," Proceeding o the Internatioanl Conference on Advanced Science, Engineering and Information Technology 2011, (pp. 200-205). Putrajaya, 2011.

[16] E. Md. Noah, "Determining the potential barriers to ERP system adoption: A study on SMEs in Klang Valley", (Bachelor dissertation, University Teknologi MARA, UiTM, 2005), 2005.

[17] T. Wailgum, (2007, March 7). ERP Definition and Solution:CXO Media Inc. Retrieved September 9, 2010, from CXO Media Inc Web site: http://www.cio.com

[18] F. Bergeron, L. Raymond, S. Rivards and M-F, Gara, "Determinant of EIS use: Testing a behavioral model," Decision Support System , vol.14, pp. 131-146, 1995.

[19] M. Bina, D.Karaiskos, and G. Giaglis, "Investigating Factors Affecting Actual Usage Patterns of Mobile Data Services," Proceedings of the 2007 Los Angeles Global Mobility Roundtable. Los Angeles, 2007.

[20] R. Thompson, C. Higgins, and J. Howell, "Influence of Experience on Personal Computer Utilization: Testing a Conceptual Model," Journal of Management Information System, vol. 11 (1), pp. 167-187, 1994.

[21] C. Holland, and B. Light, "A Critical Success Factors Model for ERP Implementation,” IEEE Computer Society , pp. 30-36, 1999.

[22] T. Somer, and K. Nelson, "A taxanomy of players and activities across the ERP project life cycle," Information \& Management, pp. 41, 257278, 2004.

[23] Y. Xue, H. Liang, W. Boulton, and C. Synder, "ERP implementation failures in China: Case studies with implementation for ERP vendors," International Journal Production Economics, vol. 94, pp. 279-295, 2005.

[24] Z. Zhang, M. Z. Lee, and Z. Huang, "A framework of ERP systems implementation success in China: An empirical study," International Journal Production Economics, vol. 98, pp. 56-80, 2005.

[25] I.Ehie, and M. Madsen, "Identifying critical issue in enterprise reseource planning (ERP) implementation," Computer in Industry , pp. 545-557, 2005.

[26] M-K. Chang, W. Cheung, C-H, Cheng, and J. Yeung, "Understanding ERP system adoption from user's perspective," International Journal of Produsction Economics , vol. 113, pp. 928-942, 2008.

[27] M. Rashid, L. Hossain, and J. Patrick, "The Evolution of ERP Systems: A Historical Perspective. Idea Group Publishing," 2002.
[28] P. Baltzan, A. Philips, and S. Haag, "Business Driven Technology" (3rd ed.). Singapore: McGraw Hill, 2009.

[29] J. Ramjattan, "User Acceptance in System Implementation. Magazine voor Informatiemanagement," New York, USA. Vol. 8(1), December 2008.

[30] Y-Y, Shih, and S-S, Huang, "The Actual Usage of ERP Systems: An Extended Technology Acceptance Perspective," Journal of Research and Practice in Information Technology, vol. 41 (3), pp. 263-276, 2009.

[31] K. Gyampah, and A. Salam, "An Extension of the technology acceptance model in an ERP implementation environment," Information \& Management, vol. 41, pp. 731-745, 2004

[32] A. Bajaj, and S. Nidumolu, "A feedback model to understand information system usage," Information \& Management, vol. 33, pp. 213-224, 1998.

[33] F. Davis, R. Bagozzi, and P. Warshaw, "User Acceptance of Computer Technology: A Comparison of Two Theoritical Models," Management Science, vol. 35 (8), pp. 982. 1989.

[34] C. Gumussoy, F. Calisir, and A. Bayram, "Understanding the behavioral intention to use ERP systems: An extended technology acceptance modeL," IEEE , pp. 2024-2028, 2007.

[35] S. Blackwell, and C. Charles, "Ready, set, go: examining student readiness to use ERP technology," The Journal of Management Development ,vol. 25 (8), pp. 795-805, 2006.

[36] E. Kamhawi, "Enterprise resource planning system adoption in Bahrain: motives, benefits and barriers," Journal of Enterprise Information Management, vol. 21 (3), 310-334, 2008.

[37] V. Genoulaz, and P-A, Millet, "A classification for better use of ERP systems," Computers in Industry, vol. 56, pp. 537-587, 2005

[38] S. Kanwal, and I. A. Manarvi, "Evaluating ERP Usage Behavior of Employees and Its Impact on their Performance: A Case of Telecom Sector," Global Journal of Computer Science and Technology, bol. 10 (9), 34-41, 2010.

[39] M. Supramaniam, and Kuppusamy, "Investigating the Critical Factors in Implementing Enterprise Resource Planning system in Malaysian Business Firm," World Academy of Science, Engineering and Technology , pp. 332-341, 2009.

[40] F. Davis, "Perceived Usefulness, Perceived Ease of Use, and User Acceptance of Information Technology," MIS Quarterly, 319-393, 1989.

[41] F. Calisir, C. Gumusomy, and A. Bayram, "Predicting the behavioral intention to use the enterprise resource systems: An exploratory extension of the technology acceptance model", Management Research News , 32 (7), 597-612, 2009

[42] U. Sekaran, "Research Methods for Business: A Skill Building Approach (4th ed.)," United States of America: John Wiley \& Sons, 2003.

[43] S. Coakes, L. Steed, and O. Clara, " SPSS Version 16.0 for Windows: Analysis without Anguish," Australia: John Wiley \& Sons, 2009.

[44] A. Field, "Discovering Statistics Using SPSS (Third Edition ed.)," Singapore: SAGE Publications Asia-Pasific Pte Ltd, 2009.

[45] Y. Shih, "The effect of computer self-efficacy on enterprise resource planning usage", Behavior \& Information Technology , 25 (5), 407-411, 2006.

[46] Z. Garaca, "Factors related to the intended use of ERP systems", Management, 16 (2), 23-42, 2011 